\title{
Analisis Perlakuan Akuntansi Asset Biologis Berdasarkan PSAK 69 Pada Organisasi Simantri Kelompok Tani Ternak Sapi "Sato Amerta Utama"
}

\author{
I Kadek Agus Setya Mahendra', I Putu Gede Diatmika ${ }^{2}$ \\ 1,2 Program Studi S1 Akuntansi, Universitas Pendidikan Ganesha \\ Singaraja, Indonesia \\ e-mail: 1 agusmahendra422@gmail.com ${ }^{2} \mid$ gede.diatmika@undiksha.ac.id
}

\begin{abstract}
Abstrak
Asset biologis merupakan asset berupa hewan atau tumbuhan yang mengalami trnaformasi, sehingga mengakibatkan perubahan kualitatif maupun kuantitatif. Penerapan asset biologis sampai saat ini masih belum banyak digunakan oleh entitas yang bergerak pada entitas peternakan, padahal standar PSAK 69 berlaku di Indonesia secara aktif pada 1 Januari 2018. Penelitian ini dilakukan untuk mengetahui perlakuan akuntansi asset biologis pada organisasi Simantri kelompok ternak sapi Sato Amerta Utama, Desa Baluk berdasarkan PSAK 69. Tujuan penelitian ini untuk mengetahui pengukuran, pengakuan dan pengunggkapan asset biologis pada Simantri Sato Amerta. Penellitian ini dillakukan dengan metode kualitatif. Data diperoleh dari hasil wawancara, observasi dan dokumentasi. Selanjutnya data dari hasil tersebut dianalisis dengan reduksi data, penyajian data dan penarikan kesimpulan. Riset ini bertujuan untuk memahami perlakuan akuntansi asset biologis berdasarkan PSAK 69 pada organisasi Simantri kelompok ternak sapi Sato Amerta Utama Desa Baluk berdasarkan PSAK 69. . Dalam penelitian ini, untuk mendapatkan keabsahan data dillakukan dengan triangullasi. Capaian dalam riset ini memperlihatkan bahwa terkait dengan pengukuran, pengakuan dan pengungkapan asset biologis pada Simantri Sato Amerta Utama belum sepenuhnya sesuai dengan standar yang berlaku yaitu PSAK 69. Dilhat darii pengukuran masih mengggunakan biaya historis sebagai harga perolehan dan pencatatan yang masih sederhana.
\end{abstract}

Kata kunci: asset, biologis, perlakuan, akuntansi.

\begin{abstract}
Biological assets are assets in the form of animals or plants undergoing transformation, resulting in qualitative and quantitative changes. The application of biological assets to date has not been widely used by entities engaged in livestock entities, even though the PSAK 69 standard is active in Indonesia on January 1, 2018. This research was conducted to determine the accounting treatment of biological assets in the Simantri organization Sato Amerta Utama cattle group , Baluk Village based on PSAK 69. The purpose of this study was to determine the measurement, recognition and disclosure of biological assets in Simantri Sato Amerta. This research was conducted using qualitative methods. Data obtained from interviews, observations and documentation. Furthermore, the data from these results are analyzed by data reduction, data presentation and conclusion drawing. This research aims to understand the accounting treatment of biological assets based on PSAK 69 in the Simantri organization of the Sato Amerta Utama cattle group in Baluk Village based on PSAK 69. In this study, to get the data validity is done by triangulation. Achievements in this research show that related to the measurement, recognition and disclosure of biological assets in Simantri Sato Amerta Utama is not fully in accordance with applicable standards, namely PSAK 69. See from the measurement still uses historical costs as acquisition prices and recording is still simple.
\end{abstract}

Keywords : assets, biological, handling, accounting. 


\section{Pendahuluan}

Pada saat ini informasi merupakan sebuah komoditas yang sangat penting, dikatakan demikian sebab informasi memiliki peranan yang penting dalam kehidupan. Dalam kehidupan sehari-hari tanpa kita sadari bahwa siapapun yang mampu menguasai informasi maka ialah yang mampu mendominasi. Maka dapat dikatakan, sangatlah besar peran dari informasi bagi kehidupan. Ketersediaan akan informasi pada saat ini menjadi bagian yang penting dalam pengambilan keputusan. Sebagaimana kita ketahui, setiap keputusan yang diambil tentu didasari atas berbagai pertimbangan-pertimbangan yang di dapat dari informasi- infomasi yang ada. Maka dari itu, terkait dengan kualitas dari sebuah keputusan sangat di pengaruhi oleh seberapa besar kapasitas atau banyak atau tidaknya informasi yang mampu didapatkan dan juga seberapa relevan dan andal informasi tersebut dapat dipergunakan sebagai dasar pertimbangan untuk mengambil sebuah keputusan. Salah satu bentuk informasi yang ada dalam ilmu ekonomi yaitu berupa laporan keuangan. Menurut Kieso (2002) laporan keuangan dapat didefinisikan sebagai sarana pengkomunikasian dari sebuah informasi keuangan yang ditujukan kepada pihak-pihak eksternal.dalam laporan keuangan dimuat tentang histori dari entitas yang dikuantifiikasi dalam nilai moneter. Adapun informasi yang termuat pada laporan keuangan akan disajikan dalam bentuk neraca, laporan laba rugi, laporan perubahan modal, dan laporan arus kas serta adanya catatan atas laporan keuangan. Sebuah laporan keuangan ini akan memberikan informasi berkaitan dengan posisi keuangan, kinerja keuangan, dan perubahan posisi keuangan

Ditijau dari PSAK 1 (2009), laporan keuangan merupakan sebuah penyajian yang terstrukktur atas posisi keuangan dan kinerja keuangan suatu entitas. Bedasarkan PSAK 1 (2009) memberikan informasi berkaitan dengan posisi keuangan, kinerja keuangan, dan arus kas entitas yang bermanfaat bagi kalangan penggunaa laporan dalam pembuatan keputusan merupakan tujuan dari laporan keuangan. Selain itu, laporan keuangan merupakan perwujudan dari pertanggungjawaban yang dilakukan oleh pihak internal atas kegiataan dan penggunaan sumber daya yang dimiliki sebuah entitas serta dipergunakan sebagai roda bisnis entitas itu sendiri.

Bertolak dari upaya penyusunan laporan keuangan yang baik, ada beberapa hal yang harus diperhatikan salah satunya berkaitan dengan pemillihan dan pengggunaan metode akuntansi yang tepat. Penggunaan metode akuntansi harus diisesuaikan dengan jenis industri yang diijalankan oleh entitas. Dari segi jenis industri serta skala kegiatan entiitas yang berbeda akan menyebabkan pemillihan dan penggunaan metode akuntansi yang berbeda pula. Memilih metode akuntansi yang tepat yang dipergunakan oleh entiitas akan dapat memastikan kesesuain dalam pengungkapan, pengukuran, penyajian dan pengungkapan untuk masing-masing elemen dalam laporan keuangan dengan standar yang berllaku. Entitas yang bergerak di sektor industri agribisnis, yang utamanya sektor peternakan adalah salah satu contoh dari entitas dengan karakteristik khusus berkaitan dengan penyusunan laporan keuangannya. Hal ini mendorong minat masyarakat pedesaan yang mempunyai penghasilan menengah kebawah tertarik dalam industri agrikultur, khususnya sektor peternakan. Adapun salah satu dari wilayah di Indonesia dengan masyarakatnya banyak berkecimpung di sektor peternakan adalah Bali.

Bali adalah salah satu wilayah tingkat I yang ada di Indonesia, yang masyarakatnya banyak menjadi peternak khususnya peternak sapi Bali. Banyaknya masyarakat yang bertenak sapi khususnya sapi Bali, mendapat tanggapan dan dukungan penuh oleh pemerintah Provinsi Bali. Hal ini dibuktikan dengan dibuatnya program SIMANTRI ( Sistem Manajemen Pertanian Terintegrasi ) yang di prakarsai oleh Bapak Gubernur Bali I Made Mangku Pastika. Kegiatan Simantri di Bali untuk pertama kali dimulai di tahun 2009 tepatnya dilaksanakan di sepuluh lokasi Gapoktan, Simantri dikatakan sebagai awal kegiatan percontohan program, dengan pengalokasian dana kurang dari Rp 200 juta diperuntukan untuk masing-masing lokasi ( satu Gapoktan), dimana dana yang diberikan dalam bentuk bansos (Anugrah,dkk; 2014). Hingga saat ini program Simantri masih terus dilanjutkan oleh pemerintah Provinsi Bali. Salah satu kelompok Simantri yang ada di Jembrana yaitu kelompok Simantri "Sato Amertha Utama" yang di ketuai oleh I Nengah Mertayana. 
Kelompok Simantri ini dibentuk pada tahun 2011 dan telah memenangkan perlombaan Simantri tingkat Provinsi Bali yang diadakan pada tahun 2018 lalu dengan penilaian dilakukan beberapa bulan sebelumnya. (www.mediapelangi.com). Dalam perlombaan Simantri berprestasi ini, Simantri Sato Amertha Utama mampu mendapat juara I. Simantri ini memiiliki asset biologis berupa ternak sapi.

Asset biologis merupakan asset yang dapat dikatakan unik dengan memiliki karakteristik yang khas,dikatakan demikian karena asset biologis mengalami transformasi pertumbuhan yang kemungkinan masih bisa terjadi setelah asset biologis menghasiilkan sebuah output. Adapun transformasi yang terjadii pada asset biologis ini meliputi dari proses pertumbuhan, degenerasi, produksi dan prokreasi yang mana dari proses transformasi yang telah dialami ini dapat menimbulkan berbagai perubahan baik itu dari segi kualitatif atapun kuantitatif dalam kehidupan asset berupa tumbuhan ataupun hewan. Asset biologis ini akan mamput menghasilkan asset baru yang terwujud dalam agrikultural produce atau berupa tambahan asset biollogis dalam jenis dan kelas yang sama. Dengan adanya transformasi biologis pada asset biologis, sudah dipastikan akan diperlukannya pengukuran yang mampu menunjukkan dan menyajikan value dari asset tersebut secara wajar sesuai dengan kesepakatan dan kontribusinya dalam menghasilkan alliran keuntungan yang ekonomis bagi perusahaan.

Berkaitan dengan hal tersebut, entitas yang bergerak di bidang industri peternakan juga wajib untuk menyusun laporan keuangannya yang sesuai dengan standar yang berlaku di Indonesia. Standar akuntansi keuangan menjadi pedoman utama dalam menyusun laporan keuangan.Berkait dengan pengelolaan asset biologis pada entitas bisnis peternakan yang menjadi isu permsalahan dalam riset ini, standar akuntansi di Indonesia yaitu SAK telah mempersiapkan peraturan berkaitan dengan asset biologis yaitu SAK No. 69.Ikatan Akuntansi Indonesia (IAI) menyiapkan PSAK 69 yang telah disahkan oleh Dewan Standar Akuntansi keuangan (DSAK) dimana PSAK 69 merupakan pengadopsian dari IAS 41 yang berlaku secara efektif pada tanggal 1 Januari 2018.

Perlakuan akuntansi yang dilakukan oleh Simantri Sato Amertha Utama belum sesuai dengan PSAK 69, yang menyatakan asset biologis di ukur atas dasar nilai wajar. Asset biologis diharuskan untuk diukur pada saat pengakuan awal dan juga pada saat tanggal pelaporan berikutnya sesuai dengan nilai wajar dikurangi atas estimasi biaya penjualannya, terkecuali nilai wajar tidak mampu diukur secara andal. Terkait dengan keuntungan ataupun kerugian dari perubahan nilai wajar dari asset akan diakui dalam laba rugi terjadinya.Dengan demikian, penerapan PSAK 69 pada kelompok Simantri Sato Amertha Utama sangat diperlukan, namun faktanya banyak entitas di bidang peternakan khususnya kelompok Simantri yang belum menerapkan PSAK 69 sebagai dasar perlakuan akuntansi terkait asset biologis. Riset ini bermaksud untuk menganalisis perlakuan akuntansi asset biologis pada kelompok Simantri dengan standar akuntansi yang mengatur tentang asset biologis yaitu PSAK 69.

\section{Metode}

Riset ini adalah riset dengan menggunakan metode kualitatif. Metode kuliatatif merupakan riset deskriptif yang lebih menekankan pada data yang berupa kata-kata, gambar, dan bukan berupa angka-angka. Riset dengan metode kualitatif berbanding terbalik dengan metode kualitatif. Metode kualitatif tidak menekankan pada statistika tetapi lebih kepada deskriipsi tentang pemahaman, pemaknaan, selera dan juga motivasi serta pengallaman subjektif manusia terhadap suatu reallitas seperti tercermiin pada tiindakan atau ucapannnya dalam hubungan dengan orang lain secara holistik. Dengan demikian dapat didefinisikan bahwa riset kualitatif sebagai riset yang digunakan untuk meneliti pada kondisi objek alamiah yang mana peneliti merupakan instrumen kunci (Sugiyono, 2009).

Dalam riset kualitatif, sesuai dengan jenis riset ini data yang didapat baik berupa data tertulis ataupun lisan merupakan senjata utama untuk memecahkan isu yang ada. Menurut Atmadja ( 2013 ), ada beberapa metode yang digunakan dalam riset kualitatif diantaranya ; metode wawancara mendalam, metode observasi, metode kajian pustaka, metode kajian 
dokumen, metode historis, metode studi kasus dan metode etnografi. Dalam riset ini, peneliti mengumpulkan data menggunakan teknik observasi, wawancara dan studi dokumentasi

Menurut Spradley (Sugiyono, 2017: 215) menjelaskan bahwa pada riset kualitatif tidak mempergunakan istilah populasi, tetapi "social situasion" atau situasi social yang meliputi tiga faktor yaitu : tempat ( place ), pelaku ( actors ), dan aktivitas ( activity), dimana ketiga faktor tersebut saling berinteraksi secara sinergis. Situasi social juga dapat disamakan sebagai objek riset yang ingin diketahui tentang apa yang terjadi di dalamnya. Pada situasi sosial atau objek riset tersebut, peneliti dapat mengamati secara mendalam aktivitas ( activity) orang- orang ( actors ) yang ada pada tempat ( place ) tertentu. Adapun objek yang diteliti dalam riset ini adalah perlakuan asset biologis berdasarkan PSAK 69 pada Simantri Sato Amertha Utama. Dalam riset kualitatif menurut Sugiyono ( 2017; 216 ) sampel riset bukan dinamakan responden, tetapi sebagai narasumber, partisipan, atau informan yang merupakan subjek dalam riset kualitatif. Menurut Moleong (2010) subjek riset adalah seorang informan yang dimanfaatkan untuk memberikan informasi tentang situasi serta kondisi riset. Dalam riset ini penentuan subjek atau informan ditunjuk secara purposive atau berdasarkan pertimbangan tertentu. Peneliti memilih informan dengan pertimbangan bahwa informan tersebut memiliki pengetahuan dan pemahaman yang lebih luas mengenai hal yang diteliti sebagaimana dirumuskan dalam riset.

Anallisis data adalah upaya dalam mencari serta menata secara sistematis atas catattan hasil penenelitian dari tahapan observasi, wawancara, dan lainnya dalam upaya meningkatkan pemahaman peneliti berkaitan dengan kasus yang ditelliti dan menyajikannya. Tahapan analisis data dalam riset ini menggunakan model Miles dan Humbermen, yang terdapat dalam buku "Metode Penelitian Kualitatif" (Moleong, 2006 ) yaitu meliputi : Pengumpulan data, Reduksi data, Penyajian Data, Analisis Data dan Penarikan Kesimpulan

Dalam riset ini, untuk mendapatkan keabsahan data dilakukan dengan triangullasi. Triangullasi merupakan sallah satu cara untuk memeriksaan keabsahan data dengan memanfaattkan sesuatu yang lain di luar data itu dalam upaya pengecekan atau sebagaii pembandiing terhadap data itu (Moleong, 2006). Dalam upaya untuk memenuhi keabsahan data pada riset ini dilakukan triangulasi dengan sumber. Menurut Nugrahani (2014), triangullasi dengan sumber dapat dinyatakan sebagai upaya membandingkan dan mengecek ballik derajat kepercayaan dari suatu informasion yang diperoleh dengan waktu dan alat yang berbeda dalam riset kualitatif, sebab data yang sejenis akan lebih mantap keberadaannya apabila digali dari sumber yang berbeda.

\section{Hasil Dan Pembahasan}

Sistem Pertanian Terintegrasi (Simantri) merupakan program yang di luncurkan oleh Pemerintah Provinsi Bali pada tahun 2009 sebagai bentuk perhatian pemerintah dengan tujuan mempercepat berkembanggnya pertanian di pedesaan sekaligus mengurangi kemiskinan dan penganggguran di pedesaan. Peningkatan pendapatan dan kesejahteraan petani dengan meningkatkan jumllah produksi dari usaha Simantri merupakan tujuan dari pelaksanaan Simantri ( Dewi, dkk, 2017)

Program Simantri yang dilaksanakan oleh Pemerintah Provinsi Bali telah memperoleh dukungan pendanaan, fasilitias, dan komitmen secara politik dari Gubernur melalui penganggaran yang berkelanjutan. Merujuk pada Anugrah,dkk (2014) perkembangan jumlah Gapoktan Simantri jlid I sudah melebihi dari 400 Gapoktan, dari 1.000 Gapoktan Simantrii yang telah ditargetkan sebelumnya, hingga proses pelaksanaan kebijakan program Simantri Jilid II di 9 kabupaten atau kota yang ada di Provinsi Bali. Selain upaya yang sudah dillakukan oleh Pemerintah Provinsi Bali melalui inisiasi program Simantri jilid I dan keberlanjutan dari program tersebut dampak dari program tersebut sampai sekarang pula kepada akumulasi dari jumlah asset ternak sapi sebagai investasi, pengembangan, dan sumber pangan hewani, tetapi juga berdampak secara nyata ikut berpengaruh dalam potensibagi pengembangan usaha tani (agribisnis) ternak dan tanaman basis integrasi serta usaha lain berbasiis sumber daya lokal yang dikellola oleh masing-masing Gapoktan. 


\section{Pengukuran Asset Biologis}

Menurut Putra, dkk ( 2016 ) berpendapat terkait pengukuran yang mendefinisikan pengukuran sebagai penentuan jumlah harga yang harus diberikan pada asset pada saat terjadinya suatu transaksii. Pengukuran sendiri adalah bagian dalam ilmu akuntansi yang berguna untuk menghasilkan sebuah laporan keuangan yang andall, karena nilai yang termuat dalam laporan keuangan akan menjadi salah satu pertimbangan dalam pengambilan keputusan oleh pengguna informasi tersebut. Sehingga diharapkan adanya standar yang tepat dalam menentukan pengukuran yang paling memungkiinkan untuk asset biologis, yang saat ini telah di siapkan PSAK 69.

Berdasarkan hasil wawancara dengan I Nengah Mertayana selaku ketua Simantri Sato Amerta Utama terkait dengan pengukuran asset biologis pada saat penjualan, beliau menjelaskan sebagai berikut,

"Terkait proses penjualan sapi nike, biasanya menjual anakan sapi diumur 2-3 tahun. Untuk harga jualnya, kami mengkirakan sekiranya berapa biaya-biaya yang telah kami keluarkan selama sapi tersebut di pelihara dan nanti dari pihak pembeli juga akan menawarkan harga yang sekiranya ia berani beli, secara cawanganlah bahasa gampangnya."

Lebih lanjut lagi peneliti menanyakan kembali kepada Bapak Dewa Ketut Kariada selaku wakil ketua Simantri Sato Amerta Utama, beliau menjelaskan sebagai berikut

"Kalau masalah penjualan nike, dari pihak kami menjual anakan sapi berdasarkan harga kisaran nike. Kami perkiraan berapa biaya-biaya yang dikeluarkan, kita tentukan dengan harga berapa akan dijual. Lalu kami cari sedagar atau kadang sedagar yang datang langsung untuk melihat sapi yang akan dijual nike. Kalau harga cocok dan sepakat ya langsung diangkut"

Berdasarkan hasil wawancara diatas dengan beberapa informan menyebutkan asset biologis di organisasi Simantri Sato Amerta Utama difokuskan terhadap indukan dan anakan sapi sebagai komoditi utama organisasi Simantri Sato Amerta Utama. Pengukuran asset biologis pada Simantri Sato Amerta Utama diukur sebesar harga perolehan dengan menggunakan metode garis lurus sebagai metode penyusutannya. Berdasarrkan data dan keterangan, peneliti dapat melihat bahwa harga pasar tidak begitu berpengaruh terhadap penjualan ternak sapi, karena harga ternak sapi ditentukan oleh pemilik dan tengkulak, antara pemilik dan tengkulak saling tawar menawar antara kedua belah pihak. Harga pasar yang tersediia di Indoneisa belum dapat digunanakan sebagai dasar pengukuran atas nilai asset biologis yang dimiliki simantri ini, peneliti dapat melihat bahwa harga pasar sebagai dasar terhadap penjualan ternak sapi hal ini diikarenakan masih banyak terdapat estimasi piihak-piihak tertentu yang belum seragam disetiap daerah.

\section{Pengakuan Asset Biologis}

Asset biologis merupakan asset yang mengalami transformasi, asset yang akan mengalami pertumbuhan setiap waktu sehinggga pengakuan atas asset biologis dilakukan dari anakan sapi sampai besar menjadi indukan. Pada saat biaya-biaya yang dikeluarkan untuk ternak sapi harus dicatat sampai dengan tersebut panen. Pengakuan (recognition) dapat dinyatakan sebagai sebuah proses dalam pembentukan suatu post yang telah memenuhi defiinisi unsur dan kriteria pengakuan dalam laporan posisi keuangan atau laporan laba rugi (Cahyani \& Aprilina, 2014). Perusahaan atau entitas bisnis harus mengakui asset tersebut apabila asset yang dimaksud memberi kontribusi ataupun memberikan manfaat pada perusahaan ataupun entitas pada masa yang akan datang.

Pengakuan asset biologis Simantri Sato Amerta Utama berdasarkan hasil wawancara dengan Bapak I Nengah Mertayana selaku ketua terkait dengan pengakuan ternak sapi, beliau menjelaskan sebagai berikut, 
"Dari awal terbentuknya organisasi niki, jumlah sapi nike sebanyak 20 ekor sapi betina. Sapi ini merupakan bantuan dari pemerintah yang diberikan pada awal terbentuknya simantri, ke 20 sapi tersebut dibagi kepada setiap anggota untuk mengurusnya. Sapi-sapi betina ini tergolong indukan yang sudah siap untuk reproduksi. Sampai akhirnya sapi betina dikawinkan, terhitung selama 9 bulan sapi betina mengandung. Setelah kurang lebih diumur 6 bulan keatas, anakan sapi dengan kondisi sehat, anakan sapi ini sudah siap dijual. Apabila anakan sapi ini laku terjual, maka keuntungan yang didapat dibagi sesuai persentase yaitu sebesar 30\% masuk kas kelompok dan 70\% akan didapat oleh anggota yang memelihara sapi tersebut."

Lebih lanjut peneliti kembali menanyakan kembali kepada Bapak I Ketut Bagiasa selaku bendahara Simantri Sato Amerta Utama, beliau menjelaskan sebagai berikut

"Simantri ini pada saat awal pendirian mendapat bantuan sapi sebanyak 20 ekor, tiap anggota bertanggungjawab atas 1 ekor sapi. Ternak sapi nike lantas dikembangbiakkan, setelah ternak sapi ini memiliki anak, anggota bisa memilih anakan sapi nike dijual atau mau dipelihara. Apabila dijual nanti pembagian hasil penjualan anakan sapi tersebut dibagi sebesar persentase yang sudah ada, $70 \%$ hak milik anggota yang memelihara sapi tersebut, $30 \%$ lagi masuk ke kas kelompok. Nanti akan dicatat sebagai penambahan kas akibat penjualan sapi atau anak sapi. Dicatatnya di debet sebesar jumlah penjualan dan di kredit sebagai penjualan ternak"

Berdasarkan hasil wawancara yang telah dilaksanakan bersama beberapa narasumber di Simantri Sato Amerta terdapat perbedaan atas ketidak sesuaian dengan pengakuan atas asset biologis menurut PSAK 69. Dasar pengakuan asset biologis pada Simantri Sato Amerta Utama belum sepenuhnya mengadopsi perlakuan akuntansi sesua dengan standar yang berlaku, hal ini dapat dillihat pada laporan keuangan yang telah disajiikan sangat sederhana, karena kurangnya pengalaman, pengetahuan, dan pelatihan yang dimiliki oleh anggota kelompok. Dasar pengakuan dari asset biologis pada Simantri Sato Amerta Utama adalah nilai historis, karena harga pasar ternak sapi khususnya sapi bali tidak dapat dijadikan patokan, hal ini belum sesuai dengan standar yang berlaku yaitu PSAK 69 yang mengharuskan asset biologis diakui sebesar nilai wajarnya dan dikurangi dengan biaya untuk menjual pada pengukuran selanjutnya.

Apabila asset biologis diperoleh dari pembelian anakan sapi, maka harus diakui sebagai penambahan anakan sapi pada pengakuan awal. Berdasarkan PSAK 69, nilai wajar digunakan untuk pengukuran asset biologis, nilai wajar yang dimaksud adalah harga yang akan diteriima untuk menjuall suatu asset atau harga yang akan dibayar untuk mengallihkan suatu liabillitas dalam transaksii teratur antara pelaku pada tanggall pengukuran. Secara sederhana nilai wajar adalah harga pasar yang digunakan dalam penjualan asset biologis, apabila entitas menggunakan harga perolehan maka selisih harga perolehan dengan nilai wajar diakui sebagai laba atau rugi neto untuk periode keuntungan dan kerugian terjadi.

\section{Pengungkapan Asset Biologis}

Pengungkapan laporan keuangan berdasarkan PSAK 69 mengatur tentang asset biologis secara khusus. Dalam PSAK 69 juga mengatur mengenai transformasi pengungkapan, hal ini karena asset biologis mengalami perubahan mengakiibatkan beberapa jenis perubahan fisiik seperti pertumbuhan, degenerasi, produksi dan prokreasi yang setiap perubahannya dapat diukur.

Menurut PSAK 69 paragraf 26 keuntugan atau kerugiian yang timbul ketika penggakuan awal asset biologis pada nilai wajar yang dikurangii biaya-biaya untuk menjual dan dari perubahan nilai bayar dikurangi biaya untuk menjual asset biologis dimasukan dalam rugii pada periiode dimana keuntungan atau kerugian tersebut terrjadi. Menurut PSAK 69 Paragraf 40 (2015) entiitas mengungkapkkan keuntungan atau kerugiian gabungan yang tiimbul selama periode berjalan pada saat pengakuan awal asset biologis dan produk agrikultur. 
Agar lebih jelas mengenai penyajian dan pengungkapan mengenai asset biologis adalah hasil wawancara dengan Bapak I Nengah Mertayana yang sampai saat ini menjadi sebagai ketua Simantri Sato Amerta Utama, beliau menjelaskan sebagai berikut.

"Untuk laporan keuangan nike bisa ditanyakan kepada bendahara karena beliau yang membawa dokumen-dokomen laporan keuangan yang dimiliki oleh simantri, karena bapaknya nike yang bertugas terkait dengan keuangan. Laporan keuangan Simantri Sato Amerta Utama tidak ada secara formal seperti ada neraca, buku besar maupun laba rugi kita tau sih memang seperti akuntansi seperti itu tapi kita masih memegang prinsip kekeluargaan atau laporan secara sederhana yang mudah dimengerti oleh anggota."

Lebih lanjut peneliti bertanya kembali kepada Bapak Dewa Ketut Kariada selaku wakil ketua Simantri Sato Amerta Utama, terkait dengan pengungkapan hibah pemerintah dalam laporan keuangan, beliau menjelaskan sebagai berikut,

"Pengungkapan bantuan pemerintah kita sama bisa dibilang sama nike, hanya pengeluaran biaya pemeliharaan dan pemasukan saja, pemerintah juga memberikan kita bantuan hanya secara cuma-cuma kenten nggih, tidak ada imbalan yang akan kami berikan kepada mereka, hanya saja dia mengontrol kegiatan kita apa sudah terlaksana atau belumnya. Keutungan yang didapat nantinya akan di masukan ke kas dan di dapat oleh si pemelihara, sesuai persetase yang ada"

Berdasarkan penjelasan dari beberapa narasumber diatas, dapat disimpulkan bahwa penyajian laporan keuangan kepada anggota di laksanakan setiap bulan dalam rapat bulanan, akan tetapi masih menggunakan pelaporan keuangan yang sederhana, hanya ada pengeluaran dan pemasukan kas. Baik itu pengungkapan pembelian anakan sapi maupun adanya hibah pemerintah yang dicantumkan pada laporan keuangan. Disamping itu ada transparansi laporan keuangan kepada anggota kelompok. Hal ini merupakan dapat memperkokoh kemajuan organisasi.

\section{Simpulan Dan Saran}

Berdasarkan hasil riset yang telah dilakukan, maka penulis dapat menyimpulkan antara lain sebagai berikut, pertama, Pengukuran yang dilakukan oleh Simantri Sato Amerta Utama masih menggunakan harga perolehan. Harga jual ditentukan oleh pemilik dan pembeli (tengkulak) masing-masing dari kedua belah pihak akan memberi harga, terjadilah tawar menawar dari kedua belah pihak, apabila tidak mendapat kesepakatan harga maka, dari pemelik ternak akan mencarai pembeli lainnya atau menunggu pembeli datang.

Kedua, Pengakuan asset biologis yang digunakan pada Simantri Sato Amerta Utama belum sepenuhnya mengadopsi asset biologis sesuai dengan standar yang berlaku yaitu PSAK 69. Hal ini dapat dilihat pada laporan keuangan yang sangat sederhana. Ketiga,Penyajian dan pengungkapan masih menggunakan pencatatan sederhana meskipun sudah menggunakan komputer, hal ini dapat dlihat pada laporan keuangan yang telah dibuat, dikarenakan kurangnya pengetahuan dan keterampilan yang dimiliki oleh anggota Simantri Sato Amerta Utama. Laporan keuangan yang disajikan akan memuat akun-akun terkait dengan pemasukan dan pengeluaran kas. Disamping itu, laporan keuangan dilakukan secara transparansi, hal ini sangat membantu dalam memajukan Simantri Sato Amerta Utama.

Berdasarkan hasil riset, peneliti menyarankan, pertama, untuk Simantri Sato Amerta Utama karena tidak adanya kepastian harga jual ternak sapi, Simantri dapat menggunakan harga yang terdapat pada pasar sehingga tidak merugikan dari pihak Simantri. Kedua, karena lambatnya pertumbuhan dan tranformasi dari ternak sapi, akan lebih baik apabila Simantri Sato Amerta Utama mampu memelihara ternak sapi dengan pakan yang dapat membantu pertumbuhan ternak lebih cepat sehingga pertumbuhan ternak lebih cepat dan ternak akan lebih berbobot. Ketiga, karena minimnya pengetahuan anggota Simantri Sato Amerta Utama terkait penyusunan laporan keuangan. Peneliti menyarankan agar dari pihak Simantri mengadakan/mengikuti pelatihan terkait dengan penyusunan laporan keuangan 
berdasarkan PSAK 69. Keempat, untuk peneliti selanjutnya, mengingat luasnya cakupan asset biologis, meliputi hewan dan tumbuhan, sekiranya riset terkait asset biologis diperluas penelitiannya dari segi jenis asset biologis yang ada maupun dari segi lokasi penelitian yang diperluas misalnya CV atau PT.

\section{Daftar Pustaka}

Anugrah, Iwan Stiasjie \& dkk. 2014. Sistem Pertanian Terintegrasi- Simantri : Konsep, Pelaksanaan Dan Perannya Dalam Pembangunan Pertanian Di Provinsi Bali. Bogor: Pusat Sosial Ekonomi dan Kebijakan Pertanian. Diakses pada tangga 25 Januari 2020.

Atmadja, Anantawikrama Tungga. 2013. Pergulatan metodologi dan penelitian kualitatif dalam ranah ilmu akuntansi. Jurnal Akuntansi Profesi. Vol. 3 No. 2.

Cahyani, Ranny \& Aprilina, V. (2014). Evaluasi Penerapan SAK ETAP Dalam Pelaporan Asset Biologis Pada Peternakan Unguul Farm Bogor. Jurnal Riset Akuntansi Dan Keuangan, Vol. 5 No.1.

Dewi, Ni Luh Putu Rosita, dkk. 2017. Faktor-Faktor Yang Mempengaruhi Produkstivitas Usaha Tani Dan Keberhasilan Program Simantri Di Kabupaten Klungkung. EJurnal Ekonomi Dan Bisnis Universitas Udayana Vol. 6 No.2.

Ikatan Akuntansi Indonesia. 2015. Pernyataan standar akuntansi keuanagn (PSAK) No.69:Agrikultur, Jakarta: IAI

Ikatan Akuntansi Indonesia. 2015. Standar Akuntansi Keuangan No.1 Penyajian Laporan Keuangan. Jakarta

Kieso, Donald E., dkk. Intermediate Accounting. $9^{\text {th }}$ Ed. New York: John willey \& Sons, Inc.

Media Pelangi. 2018. Gubernur Koster Serahkan Penghargaan Simantri Berprestasi, Bangkit Minat Masyarakat Beternak Sapi Bali.

Media Pelangi.2018. Gubernur Koster Serahkan Penghargaan Simantri Berprestasi, Bangkit Minat Masyarakat Beternak Sapi Bali.

Moleong, Lexy. J. 2006. Metodelogi Penelitian Kualitatif, Bandung. PT Remaja Rosdakarya

Moleong, Lexy. J. 2010. Metodelogi Penelitian Kualitatif, Bandung. PT Remaja Rosdakarya

Nugrahani, Farida. 2014. Metode Penelitian Kualitatif dalam Penelitian Pendidikan Bahasa. Surakarta:-

Putra, A. V. W., Pangemanan, S. S., \& Wokas, H. R. N. (2016). Analisis Perbandingan Perlakuan Akuntansi Terhadap Asset Biologis Dan Non Biologis (Studi Kasus pada CV. Fatherland Farm Tondano). Jurnal Riset Akuntansi Going Concern, Vol. 11 No. 3

Sugiyono. 2009. Metode Penelitian Kuantitatif Kualitatif dan R\&D. CV Alfabeta: Bandung

Sugiyono. 2017. Metode Penelitian Kuantitatif Kualitatif dan R\&D. CV Alfabeta: Bandung 